\title{
Genel ve Özel Amaçı Ombudsmanlık Örnekleri: İngiltere ve Türkiye
}

\author{
Examples of General and Special Purpose Ombudsman: UK and Turkey
}

\section{Emine CELIKKSOY}

Dr. Öğr. Üyesi, Çankırl Karatekin Üniversitesi, İ̈B , Siyaset Bilimi ve Kamu Yönetimi Bölümü, eceliksoy@karatekin.edu.tr https://orcid.org/0000-0001-8175-8611
Makale Başvuru Tarihi: 05.04.2020

Makale Kabul Tarihi: 11.05.2020

Makale Türü: Araştırma Makalesi

\section{Büşra BAYAN}

Yüksek Lisans Ö̈̆r., Çankırl Karatekin Üniversitesi, SBE, Siyaset Bilimi ve Kamu Yönetimi A.B.D., bsrabayan@gmail.com https://orcid.org/0000-0003-1318-4147

\section{Anahtar \\ Kelimeler:}

Genel Amaçlı

Ombudsman,

Özel Amaçlı

Ombudsman,

Ingiltere,

Türkiye,

Keywords:

General Purpose Ombudsman,

Special Purpose Ombudsman,

$U K$,

Turkey,

\section{ÖZET}

Yönetimin tamamlayıcı unsuru denetimdir. Denetim devletin etkin işlemesini să̆lamaktadır. Devletin denetlenmesinde siyasi, hukuki ve idari denetim yollarl uygulanmaktadır. Ombudsmanlık denetimi devletin diğer denetim yollarına alternatif bir denetim türü değildir, diğer denetim yollarının eksik kalan yönlerini doldurmaya yönelik bir denetim mekanizması öngörmektedir. Ombudsmanlık kurumu, günümüzde birçok ülkede uygulanmaktadır. Ombudsman vatandaşlar ile kamu kurumları arasında ortaya çıan anlaşmazlıkların giderilmesi için kurulan bağımsız bir kurumdur. Ombudsmanlık türlerini genel ve özel amaçlı ombudsmanlar olarak ikili sinıflandirabiliriz. Genel amaçlı ombudsmanlar kendilerine gelen her türlü şikayeti değerlendirmekle görevli kılınmışlardır. Genel amaçlı ombudsmanlık kurumunda ombudsmanlar konu ayrımı ve kisıtlamasına tabi tutulmamışlardır. Özel amaçl ombudmanlık kurumlarında ise ihtisas alanına göre uzmanlaşma yaşanmaktadır. Ombudsmanlar belli bir konuda uzmanlaşmakta ve yalnız bu konuda kendilerine yapılan başvuruları kabul edebilmektedir. İngiltere'de ombudsmanlık kurumu yaklaşık 50 yillık bir tecrübeye sahiptir. Birçok konuda özel ombudsmanlar kurulmuştur. Parlamento komiserliği, yerel yönetimler komiserliği, cezaevleri ve şartl tahliye ombudsmanlı̆̆ bu özel ombudsmanlık türlerinden üçüdür. Türkiye'de son 8 ylldır kamu denetçiliği yasal bir zeminde yer almaktadır. Genel amaçlı olan kamu denetçisi devletin taraf olduğu uyuşmazlıkların çözümü için öneriler sunmakta ve başarılı sonuçlar elde etmeye çalışmaktadır.

\begin{abstract}
Complementary element of management is supervision. Supervision ensures effective functioning of the state. Political, legal and administrative ways of supervision are applied in the inspection of the state. Ombudsman supervision is not an alternative type of supervision to the other ways of supervision of the state. It envisages an audit mechanism to fill in the deficiencies of other audit trails. The Ombudsman institution is practiced in many countries today. Ombudsman is an independent institution established to resolve disputes arising between citizens and public institutions. We can classify ombudsman types as general and special purpose ombudsman. General purpose of ombudsman are tasked with evaluating any complaints they receive. In the general purpose ombudsman institution, ombudsman are not liable to subject discrimination and restriction. In special purpose ombudsman institutions, specialization is experienced according to the expertise area.. Ombudsman specialize in a particular subject and can only accept applications made to them in this regard. The UK ombudsman institution has nearly 50 years of experience. Special ombudsman have been established on many issues. Parliamentary commission, local government commission, prisons and conditional release ombudsman are three of these special types of ombudsman. Ombudsman has been located in legal basis for the last 8 years in Turkey. The general purpose ombudsman is offerings suggestions for resolving disputes to which the state is a party and tries to achieve successful results.
\end{abstract}




\section{GIRISS}

Demokratik hukuk devleti ilkesi gereğince devlet vatandaşlarının temel hak ve özgürlüklerini korumalıdır. Hukukun üstünlügü ve idarenin denetimi önemlidir. Kamu yönetiminin denetlemesi iç ve dış denetimle gerçekleşmektedir. İç denetim kamu kurumunda çalışan personellerin üstleri tarafından denetlenmesidir. Dış denetim ise kamu kurum ve kuruluşlarının başka bir kurum tarafından denetlemesidir. Hiyerarşi denetimi ve idari teftiş denetimi iç denetimde, Sayıştay denetimi ve Devlet Denetleme Kurulu denetimi dış denetimi unsurlarındandır. Denetleme türlerinden bir diğeri ise ombudsman kurumu tarafindan gerçekleştirilen denetimdir. Ombudsmanlık kurumu ilk olarak İsveç’te kurulmuştur. Yolsuzlukları gidermede başarılı olan ombudsmanlık kurumu İskandinav ülkeleri tarafından uygulanmaya başlamışıtır. İkinci dünya savaşı sonrası kurumun uygulama alanı genişlemiştir. Ombudsmanın genel özellikleri bağımsız, tarafsız, dürüst, geniş araştırma yapan, masrafsız ve kolay ulaşılabilen bir kurum olmasıdır. Ombudsmana mektup, e-mail ve telefon yoluyla ulaşılabilir. Ombudsmanın inceleme yaparken her türlü bilgi ve belgeye ulaşma yetkisi bulunmaktadır. Ancak idarenin işlemlerini iptal edemez ve idarelere emir vermez. Ombudsmanın kararları bağlayıcı değildir. Çocuk Ombudsmanı, sağlık ombudsmanı, cezaevi ombudsmanı, basın ombudsmanı, polis ombudsmanı, insan hakları ombudsmanı gibi birçok türü bulunmaktadır.

Her ülkenin kendi yönetim sisteminde ombudsman farklı isimler ile ifade edilmektedir. Türkiye'de hukuki düzenlemelerde ombudsmanlık müessesesi Kamu Denetçiliği Kurumu olarak adlandırılmaktadır. Ombudsman kurumu İsveç'te kuruluşundan 158 yıl sonra 1967 yılında İngiltere'de kurulabilmiştir. Türkiye'de ise kurumun kurulmasına ilişkin ilk çalışmalara 1960'lı yıllarda yer verilmiştir. Düzenli beş yıllık kalkınma planlarında ve hükümet programlarında ombudsmanlık kurumunun kurulması dair çalışmalar yapılmıştır. Kurum Türkiye'de 2012 senesinde çıarılan 6328 sayılı Kamu Denetçiliği Kurumu Kanunu ile yasal statü kazanmıştır. Bu çalışmada dünyada yaygın bir şekilde uygulanan ombudsmanlık kurumu genel ve özel amaçlı ombudsmanlık örnekleri ile Türkiye ve İngiltere özelinde incelenecektir.

\section{KAVRAMSAL ÇERÇEVE}

\subsection{Kamu Yönetiminde Denetim}

Yönetimin tamamlayıcı unsuru denetimdir. Teşkilat içerisinde denetim mekanizmalarının varlığı gereklidir (Coşkun, 2002:90). Denetimin amacı kurumların yetki ve sorumluluklarını etkin, verimli ve hukuki bir biçimde kullanıp kullanmadıklarını kontrol etmek ve vatandaşlara kaliteli, kolay ve hızlı hizmet sunmaktır (Temizel, 1997:25).

Kamu yönetiminde denetim ifa edilen vazifelerin plan, prensip, direktif ve mevzuatlara uygunluğunun kontrolüdür. Yönetimdeki süreçlerin denetimi yöneticilerin görevlerindendir. Yönetimde etkinlik için, denetim mekanizmalarının varlığı ve işleyişi önemlidir (Aktan, 1989:137-138).

Kamu yönetiminde denetim idari kurum ve kuruluşlar tarafından gerçekleştirilebileceği gibi bunların dışında kalan kurum ve kuruluşlar tarafından da gerçekleştirilebilmektedir. İdari kurum ve kuruluşların gerçekleştirdikleri denetim idari denetim, meclis tarafından gerçekleştirilen denetime siyasi denetim, yargı organınca gerçekleştirilen denetim ise yargı denetimidir (Gözübüyük, 2008:321). Denetimler kurumun içinden bir kişi, birim tarafından ve kurumun dışından bir kişi, birim tarafından yapılmasına göre farklı tanımlanmaktadır.

İç denetim devletin içerisinde yer alan kurumların yine kendi içerisinde bulunan denetim organlarınca denetlenmesidir (Atay, 1999:38). İç denetim kurum içinde çalışan astların üstleri tarafindan denetlenmesi ile gerçekleşeceği gibi kurum içerisinde yer alan denetim organlarınca da gerçekleştirilebilir (Coşkun, 2002:87). İç denetimde ifa edilen görevlerin belirlenen politikalara uygun olup olmadığı, kamuya aktarılan kaynakların etkinlik ve verimlilik ilkelerine uygun yönetilip yönetilmediği gözlemlenmektedir. İç denetimi hiyerarşik ve idari teftiş denetimi olarak iki başlık altında incelemekteyiz (Bilge ve Daşkaya, 2015:109-110).

Hiyerarşik denetim kamu kurum ve kuruluşları bünyesinde görevli personellerin idari işlem ve eylemlerin belirli düzen içerisinde yapılması ve aksamaması için merkezdeki en üst makama bağlanması ve denetlenmesidir. Üst makamların alt kademede çalışan kamu görevlileri üzerinde hiyerarşik yetkisi vardır (Eryılmaz, 2013:388). Üst asta emir verebilir ve astı yönlendirmelidir. Ast ise amirinin emirlerine uymalıdır. Üst, astın yerine geçip işlem yapamaz. Bakan en üst yöneticidir ve astlar tarafından alınan kararlardan sorumludur. Bakan her ast1 ve üstü denetleyebilir (Uluğ, 2004:101). 
İdari teftiş denetimi de iç denetim türlerindendir. İdari teşkilat içerisindeki işlem ve eylemlerin müfettişler tarafindan denetlenmesidir. Müfettişlerce yapılan bu denetim türünde müfettişlerin doğrudan karar alma yetkileri bulunmamaktadır (Tortop ve İsbir, 2007:174). İdari teftişin amacı kamu görevlileri tarafindan sunulan hizmetlerin etkinlik ve verimliliğini sağlamak için denetlemek ve öneriler sunmaktır (Coşkun, 2002:102).Soruşturma ve inceleme sonucunda elde edilen tespitler raporlanır ve gerekli tedbirlerin alınması sağlanır.

Dış denetim idarenin kendi yapısı dışında kalan kurumlarca yapılan denetimdir (Köse, 2000:17). İdari vesayet denetimi, Sayıştay denetimi ve Devlet Denetleme Kurulu'nun denetimi dış denetimdir. İdari vesayet denetimi yerinden yönetim kuruluşlarının yönetimde birliğin sağlanması amacıyla başka bir kamu kuruluşu tarafindan denetlenmesidir (Giritli ve Bilgen, 2006:190). Farklı tüzel kişiliğe haiz kamu kurumları arasında gerçekleştirilir. İdari vesayete tabi olan kamu tüzel kişileri yer yönünden yerinden yönetim kuruluşlarıdır (Uluğ, 2004:102).

Türkiye Cumhuriyeti 1982 Anayasası'nın 127. maddesine göre idari vesayet yetkisine haiz olan merkezi idare, vesayet denetimine tabi olan mahalli idarelerdir. İdari vesayet yetkisi kamu yararına kullanılmalıdır. İdari vesayet denetiminde mahalli hizmet veren yerel yönetimlerin yetkilerini sınırlama ve alınan kararlanı önemsemeyerek atama yapma, emir verme, karar alma gibi yetkiler bulunmamaktadır (Eryılmaz, 2013:388).

Mali denetim Türkiye Cumhuriyeti 1982 Anayasası'nın 160. maddesine göre Sayıştay tarafından TBMM adına gerçekleştirilmektedir. Sayıştay'ın kamu kurumlarının gelir ve giderlerini inceleme, bu gelir ile giderler arasında uyumsuzluk varsa sorumluları bulma noktasında görevleri vardır.

Sayıştay en genel anlamda iki görevi yerine getirmektedir. İlki genel yönetim kapsamında yer alan kamu kurumlarının sunduğu mal ve hizmetler için kullandığı bütçesinin kurumun kendi hedeflerine uyup uymadığının denetlenip Türkiye Büyük Millet Meclisi'ne rapor olarak sunulmasıdır. Diğeri genel yönetim kapsamında yer alan kamu kurumlarının sunduğu mal ve hizmetler için kullandığı bütçesinin hukuki mevzuata uyup uymadığının denetlenmesidir (Kulukçu, 2006:12).

Devlet Denetleme Kurulu'nun Anayasa'nın son haline göre yargı organları haricinde bütün devlet kurumları ile kamu niteliğinde olan kuruluşlarda, kamuya yararlı dernek ve vakıflarda her türlü idari soruşturma, inceleme, araştırma ve denetlemeleri yapma yetkisi vardır. Yarg1 organları, Devlet Denetleme Kurulu'nun denetimi dışında tutulmuştur. Bu yetki anayasal bir yetkidir. 15 Temmuz 2018 tarihinde çıkarılan 5 sayılı Cumhurbaşkanı Kararnamesi Devlet Denetleme Kurulu hakkındadır. Devlet Denetleme Kurulu Cumhurbaşkanının isteği üzerine harekete geçmektedir. Yapılan denetleme, araştırma ve incelemeler Cumhurbaşkanına rapor olarak sunulmaktadır. Cumhurbaşkanınca onaylanan raporlar ilgili Bakanlığa ve diğer kuruluşlara gereğinin yapılması için gönderilir. Devlet Denetleme Kurulu'nun son anayasal değişiklikler ile güçlendirildiğini söyleyebiliriz. Bu değişikliklerden önce Devlet Denetleme Kurulu yargı organları ve Türk Silahlı Kuvvetleri'ni denetleyemiyordu (https://www.mevzuat.gov.tr/MevzuatMetin/1.5.2709.pdf, Erişim Tarihi:25.03.2020). Ombudsmanlık denetimi ise devletin diğer denetim yollarına alternatif bir denetim türü değildir. Ombudsmanlık denetimi diğer denetim yollarının eksik kalan yönlerini doldurmaya yönelik bir denetim mekanizması öngörmektedir.

\subsection{Ombudsman}

Ombudsman, günümüzde birçok ülkede uygulanmaktadır. Birçok farklı tanımı yapılabilmektedir. En genel ifadeyle ombudsman vatandaşlar ile kamu kurumları arasında ortaya çıkan anlaşmazlıkların giderilmesi için kurulan bağımsız bir kurumdur (Kazanc1, 2016:303). Ombudsman tarafsız bir birim olarak halktan almış olduğu şikayetler üzerine gerçekleştirdiği inceleme ve soruşturmaların sonuçlarını yetkililere aktaran müfettiştir (Altuğ, 2002:31).

Ombudsmanlık kurumu güvenirlik ilkesine bağlı bağımsız ve tarafsız, kolay ulaşılabilen bir kurumdur. Ombudsmanlık yeni bir denetim türü ve asli denetim fonksiyonlarına katkı sağlayacak bir türdür (Altun ve Kuluçlu, 2005:31). İsveç dilinden gelen ombudsman sözcüğü bu dilde temsilci anlamına gelmektedir (Büyükavc1, 2008:10). Kurumun tarihi temelleri yapılan çeşitli araştırmalarda Çin'e, Roma İmparatorluğu'na, Amerika kolonilerine kadar uzanmaktadır (Kılavuz vd., 2003:50).

Kurumun tarihi temelleri yapılan çeşitli araştırmalarda ombudsmanlık müessesesine ilişkin benzer uygulamaların İslam devletlerinde yer alan Divan-1 Mezalim, Muhtesip, Dar'ül Adl, Şikayetleri İnceleme Kurulu'nda da var olduğu yer almaktadır (Ökten, 2014:215).

İsveç kralı XII. Karl (Demirbaş Şarl) 1709 yılında İsveç- Rus savaşında yenilgiye uğrayıp Osmanlı İmparatorluğu'na sığınmış ve yaklaşık beş yıl burada kalmıştır. İsveç kralı XII. Karl'ın bu süre zarfinda Divan-1 
Hümayun bünyesinde yer alan Kadı-ul Kudat'lıktan etkilendiği ve kendi ülkesine bir emir gönderdiği çeşitli kaynaklarda yer almaktadır. Bu emire göre İsveç kralı XII. Karl 1713 senesinde ombudsman adında bir kamu görevlisini ülkesinde faaliyet gösteren kamu görevlilerini denetlemek üzere görevlendirmiştir. Böylelikle ombudsmanlık kurumu ortaya çıkmıştır (Fendoğlu, 2010:6; Ataman, 1997:779). Ombudsmanlık kurumunun Osmanlı İmparatorluğu'nda yer alan ahilik teşkilatından etkilenerek oluşturulmuş bir kurum olduğu da çeşitli araştırmalarda yer almaktadır (Küçüközyiğit, 2006:92).

Ombudsmanlık kurumu İsveç’te başarılı olunca önce Finlandiya tarafından da uygulanmaya başlamıştır. Uzun yıllar yalnız bu iki ekonomisi gelişmiş, nüfusu az ve merkeziyetçi olmayan ülkelerin idari sistemlerine uygun olduğu görüşü hakim olmuştur. Ombudsmanlık kurumunun gelişimi üç dalga da incelemiştir. Birinci dalga kurumun ortaya çıkması ve Finlandiya'da uygulanması ikinci dalga Danimarka, Norveç, Yeni Zelanda, İngiltere, İsrail, Fransa, Batı Almanya, Kuzey İrlanda gibi ülkeler de İkinci Dünya Savaşı'nın ardından ombudsmanlığın yayılması, son olarak Latin Amerika, Güney Afrika ve Doğu Avrupa'ya kadar birçok ülkede kurumun uygulama alanı bulması üçüncü dalga olarak ifade edilmektedir (Mutta, 2005:55).

Her ülkenin kendi yasal ve yönetsel sistemine göre isimlendirilen ombudsmanlık kurumu; Kanada'da Vatandaş Koruyucusu, Portekiz'de Adalet Temsilcisi, Avusturya'da Halkın Avukatı, Belçika'da Federal Ombudsman, Türkiye'de Kamu Denetçiliği Kurumu olarak adlandırılmaktadır (Özdemir, 2015:7). Ombudsmanlık müessesesi farklı ülkelerde farklı düzeylerde uygulanmaktadır. Tüm devlet çapında, federe birimler düzeyinde ve yerel yönetimler düzeyinde ombudsmanlara örnekler mevcuttur. Bunlarla birlikte Avrupa Birliği'nin de kendi ombudsmanlık kurumu 1992 yılından itibaren vardır (Tortop, 1998:3).

\subsection{Ombudsmanlık Türleri ve Özellikleri}

Ombudsmanlık türlerini genel ve özel amaçlı ombudsmanlar olarak ikili sınıflandırabiliriz. Genel amaçlı ombudsmanlar kendilerine gelen her türlü şikayeti değerlendirmekle görevli kılınmışlardır. Genel amaçlı ombudsmanlık kurumunda ombudsmanlar konu ayrımı ve kısıtlamasına tabi tutulmamışlardır. Genel amaçlı ombudsman klasik ombudsman olarak da çalışmalarda yer almaktadır. Klasik ombudsman konu açısından sınırlanmamıştır ancak bazen tüm ülke çapında görevli olabileceği gibi bazen bir eyalette ya da yerel yönetim düzeyinde de görevli olabilmektedir. Klasik ombudsmanı bir çok ülkede meclis seçmektedir. Ombudsmanlık kurumu günümüzde yalnız demokrasisi gelişmiş ülkeler de olan bir kurum değildir. Gelişmekte olan, idari sisteminde reform hareketleri içinde olan ülkelerde ombudsmanlık kurumu o ülkelerin gelişmesine katkı sağlayacak kurumlardan birisi olarak görülmektedir.

Ombudsmanlık kurumunun günümüzde bir çok devlette uygulama şansı bulmasının sebebi bir çok devlette başarıya ulaşmış olmasından kaynaklanmaktadır. Ancak her ülke ombudsmanlık kurumunu da kendi idari yapıları ile ihtiyaç duydukları alanlara göre düzenleme yaparak bünyesine dahil etmiştir. Özel amaçlı ombudsmanlık kurumlarında uzmanlaşma ihtisas alanina göre gerçekleşmektedir. Ombudsmanlar belirli bir konuda uzmanlaşarak, ihtisas alanlarına gore yapılan başvuruşarı kabul etmektedir. Belirli bir alanda uzmanlaşan ve bu alandaki uyuşmazlıkları çözmeye çalışan ombudsmanlara sağlık ombudsmanı, tüketici ombudsmanı ve çocuk ombudsmanı örnek verilebilir. Bazı devletlerde sadece genel amaçlı ombudsman bulunurken bazı devletlerde yanlız özel amaçlı ombudsmanlar bulunmaktadır. Bazı devletlerde ise iki ombudsmanlık türü bir arada bulunmaktadır.

Sağlık sektöründe ombudsmanlık kurumu İngiltere, Galler ve İskoçya'da ilk olarak uygulanmaya başlamıştır. Hastalardan gelen şikayetleri incelemek, hastalara yönelik kötü muameleleri azalatmak ve sağlık hizmetlerinin kalitesini arttırmak amacıyla sağlık ombudsmanı kurulmuştur ( Avşar, 2012:152). Ombudsmana başvuru ücretsizdir. Sağlık ombudsmanının incelediği konular hasta haklarının ihlaline yönelik şikayetler ve sağlık kuruluşlarında yaşanan olumsuzluklardır. Sağlık ombudsmanın işlevselliğinin artmasıyla birlikte kurumların vatandaşlara olan yaklaşımında, sunulan hizmetlerin kalitesinde önemli derecede değişiklikler yaşanmıştır (Avşar, 2012:152-153).

Savunma ombudsmanlı̆ğ yada diğer bir ifadeyle askeri ombudsmanlık Almanya'da etkin bir şekilde uygulanmaktadır. 1957 yılında çıkarılan Savunma Ombudsmanlığı hakkındaki kanun ile askeri temel haklarının korunması ve federal ordu üzerinden parlamento denetiminin etkin hale getirilmesi amaciyla kurulmuştur. Savunma ombudsmanının temel görevleri askeriyede meydana gelecek sorunların ve eksikliklerin tespit edilerek çözümlenmesi ve askeri kurum ve kuruluşların denetlenmesidir (Usta ve Akınc1,2016: 2743-2746). Federal Savunma Ombudsmanlığı, orduda ortaya çıkan aksaklıkların tespiti ve çözümünde önemli işlev sahibidir. Askeri kurum ve kuruluşlarının denetlenmesi noktasında aktif rol oynamaktadır. 
Tüketici ombudsmanı üretici ve tüketici arasındaki olumsuzlukların giderilmesi amacıyla kurulmuştur. Tüketici ombudsmanı üreticiler tarafından yapılan aldatıc1 ve yanıltıc1 hareketlerden tüketiciyi korumay1 hedeflemektedir. Tüketici ombudsmanı alıcı ile satıcı arasındaki uyuşmazlıklar yargı yoluna gidilmeden çözümlenebilmektedir (Aydın, 2018:65).

Çocuk ombudsmanlığının ilk uygulandığı devlet Norveç’tir (Fendoğlu, 2010:90). Çocuklar yetişkinler karşısında savunmasız ve korumasız oldukları için çocuk hakları ombudsmanlığı kurulmuştur (Şahin, 2015:38). Çocuk ombudsmanı çoçuklara yönelik şiddet, taciz, kötü muamale, ayrımcılık gibi sorunlarla ilgilenmektedir (Fendoğlu, 2010:17). Çocuk hakları konusunda gelen şikayetleri incelemek, gözlem ve araştırma yapmak, çocukların hayat koşullarının iyi hale getirilmesi için yetkili makamlara tavsiyelerde bulunmak çocuk ombudsmanının görevlerindendir (Özden, 2010:56-57).

Ombudsmanlık kurumunun özellikleri ülkeden ülkeye farklılıklar göstermekle birlikte hemen hemen tüm ülkelerde geçerli olan bazı özelliklere de sahiptir. Ombudsman bağımsız ve tarafsız bir kişidir. Etkili bir inceleme yapabilir. Birçok ülkede yasama organı tarafından seçilmektedir. Ombudsman kolay ulaşılabilir olmalıdır. Ombudsman görevlerini yerine getirirken her açıdan yürütme erkinin dişında olmalıdır. Ombudsman belirli bir süre için atanmalıdır ve süresi dolmadan görevden alınmamalıdır (Tortop vd., 2007:145147).

Ombudsmanlık kurumunun özelliklerinden birisi özgür olmasıdır. Ombudsmanın tüm devlet kurumlarına karşı hukuki bağımsızlığı bulunmaktadır (Özden, 2010:29). Çalışmaları sebebiyle yargı organları tarafından sorgulanamaz. Ombudsmanın hiyerarşik denetim ile idari vesayet denetiminden farkı herhangi bir kamu kurumundan emir ve talimat almamasıdır (Payaslıoğlu, 1969:7).

Ombudsmanın özelliklerinden birisi de yürütme organından bağımsız arabulucu olmasıdır. Vatandaşlar ile kamu kurumları arasında hakemlik görevi üstlenir. Bağımsızlık aynı zamanda meclise karşı da sağlanmalıdır. Ombudsmanın görev süresinin meclisin görev süresinden uzun olması da bağımsızlık ve tarafsızlık özelliğine katkı sağlamaktadır.

Ombudsmanın bağımsızlığının sağlanmasında anayasal ve yasal metinlerle güvence altına alınması, meclis tarafından atanması ve görevden uzaklaştırılamaması, mali olanaklara sahip olması ve dokunulmazlığının bulunması önem taşımaktadır (Temizel, 1997:56). Ombudsmanlık kurumunun bir diğer özelliği kolay ulaşılabilir olmasıdır. Ombudsmanın yapacağı işlerin vatandaşlara açık ve anlaşılır bir şekilde anlatılması gereklidir. Ombudsmana hangi yöntemlerle ulaşılacağının ve ombudsmanın hangi görevleri gerçekleştirebileceğinin vatandaşlara duyurulması gerekmektedir.

Ombudsmanlık kurumunun bir diğer özelliği hukuki düzenlemelerde ombudsmanlara geniş bir araştırma görevi verilmesidir. Ombudsmanlar kamu kurum ve kuruluşlarından kendi soruşturdukları konu ile ilgili bilgi, belgeleri isteyebilirler ve kamu kurumları bu bilgi ile belgeleri vermekle yükümlü kılınmıştır. Herhangi bir kamu kurum ve kuruluşunun hatası ombudsman tarafından kendisine yapılan başvuru sonucunda bulunursa bu durum ombudsman tarafindan kamuoyuna bildirilebilir, kamu kurum ve kuruluşunun kötü uygulamalarına karş1 kamuoyu oluşturulabilir. Ombudsmanlık kurumunun bir diğer özelliği ombudsman, denetim gerçekleştirdiği kamu kurum ve kuruluşlarına ve kendisine kamu yönetimlerinin denetlenmesi için başvuran vatandaşlara karş1 hukuki bir sorumluluk taşımaktadır.

\section{3. İNGILTERE'DE ÖZEL AMAÇLI OMBUDSMANLIK ÖRNEKLERİ}

\subsection{Parlamento Komiseri}

İngiltere de idari işlemleri denetlemek için ayrı mahkemeler bulunmamaktadır. Vatandaşın idari işlemlerden dolayı şikayetleri mahkeme önünde ispat edilmelidir. Diğer bir yöntem ise milletvekilleri aracıllğı ile bakanlara iletilmesidir. Bu yöntemler vatandaş açısında uzun zaman alan ve pahalı bir yöntemdir (Ataman, 1993:222). İdarenin denetimi için klasik yöntemler eksik ve yetersiz olduğu bu dönemde sık sık dile getirilmektedir. 1961 yılında Sir John Whyatt tarafından sunulan raporla vatandaş ile devlet arasında çıkan sorunların çözümlenmesi için ombudsmanlık kurumunun kurulması önerilmiştir (Arı, 2017:139). Dönemin hükümeti kuruma sicak bakmasa da kamunun denetimi için yeni yöntemlerin olması gerektiği ilerleyen yıllarda ki hükümet tarafindan kabul görmüştür. Parlamento Komiserliği 1967 yılında ki çıkarılan kanunla yasallık kazanmıştır. İlk zamanlarda parlamento komiserliğin yetkileri oldukça az olsa da zaman içerisinde görevleri artmıştır (Ataman, 1993:222). 1966 yılında Parlamento Komiserliği ataması yapılmış ve şikayetler incelenmeye başlanmıştır. Parlamento Komiseri ayrıca sağlık hizmetleri ombudsmanlığına da atanmıştır. Parlamento Komiserinin başarısı üzerine 
sağlık ombudsmanı, yerel yönetimler ombudsmanı, hapishane ombudsmanı, finans ombudsmanı gibi çeşitli ombudsman kurumları oluşturulmuştur (Erdoğmuş, 2006:51).

Parlamento Komiseri Kraliçenin parlamentoya yazdığı mektup ile göreve başlamaktadır (Ataman, 1993:222). Parlamento komiseri kamara üyelerinden seçilmemektedir. Ombudsmanlığa ayrılan ödenek devlet gelirlerinden karşılanmakta ve Avam Kamarası tarafindan ödenecek miktar belirlenmektedir. Görev süresi belli olmayan Komiser görevinin kurallarına uyduğu takdirde 65 yaşına kadar görevini ifa edebilir. Ancak kurallara uymayıp başarısız olan Komiser, Lordlar ve Avam kamarası kararı sonrası Kraliçe tarafından görevden alınabilir (Erdengi, 2009:86-87).

Parlamento Komiseri Yasası ile kamu hizmeti görmek amacıyla kurulmuş kamu kurumları ile yerel yönetimler, Kraliçe'nin üyelerini atadığı kamu kurumları, Bakanlar, bütçesi Parlamento tarafından karşılanan kurum ve kuruluşların şikayette bulunması engellenmiştir. Parlamento Komiserine ilgililer direk başvuruda bulunamazlar ve Parlamento Komiseri de gerekli aşamalardan geçilmeden doğrudan soruşturma başlatamaz (Arslan, 1986:161-162).

Avam kamarasına şikayet yazılı yapılmaktadır. Parlamento Komiseri gelen şikayetleri direkt kabul edememektedir. Şikayetler Avam Kamarası üyeleri aracılığı ile Parlamento Komiserine iletilmektedir. Mağdur olan kişi durumdan haberdar olduğunda 1 yıl içinde başvurusunu Avam Kamarasına yapmalıdır (Arslan, 1986: 162). Parlamento Komiserine başvuru ücretsiz olup, Lordlar Kamarasına şikâyet yapılmamaktadır. Parlamento komiseri çalışmalarını isteğe bağlı olarak gizlilikle sürdürebilir. Parlamento komiseri çalışmalarında bağımsızdır ve hiyerarşik bir üstü bulunmamaktadır (Çakmak, 2008:66-72).

\subsection{Yerel Yönetim Ombudsmanı}

Yerel yönetimlerin işlemleri için şikayet mekanizması İngiltere'de 1974 yılında Yerel Yönetim Yasası'yla oluşturulmuştur (Arap, 2015:68). Yerel yönetim komiserinin görev alanı belediyeler ve bazı kamu kurumlarıdır. Köy ve kasaba görev alanı dışındadır (Zengin, 2017:45). Yerel yönetim ombudsmanlığı teşkilat yapısı komisyondan, kurumun memurlarından ve ombudsmandan meydana gelmektedir. Yerel yönetim ombudsmanlığının kurulduğu yıllarda üç bölgede ombudsmanlık bulunmaktadır. 2010 yılında yapılan değişiklikle bölge düzeyinden konu düzeyine geçilmiş olup üç bölge, iki bölgeye düşürülmüştür. 2012 yıllndan sonra ise bir ombudsman görev yapmaktadır (Arap, 2015:69).

Yerel Yönetimler Bakanı'nın önerisi Kraliçe'nin onayı ile yerel yönetim komiseri atanmaktadır (Zengin, 2017:45). Yerel yönetim komiserinin iki amacı bulunmaktadır. Birincisi şikayetleri araştırmak ikincisi ise yerel yönetimlere tavsiyede bulunmaktır. Yerel yönetim komiserinin görev alanı eğitim, planlama, çevre, barınma, sosyal yardım, ulaşım, atık ve belediye vergileridir. Şikayeti hakkında hizmet sunan yerel yönetimlerce sorununun çözümüne ulaşamayan veya çözümden tatmin olmayan vatandaş 12 ay içerisinde yerel yönetim ombudsmanına başvurmalıdır (LGO, 2013). Ombudsmana başvuruda 1988 yılında yerel meclis üyesi referansı, 2007 yılında ise yazılı başvuru koşulu kaldırılmıştır (Arap, 2015:69). Yerel yönetim ombudsmanının kararları tavsiye niteliğindedir ve yaptırım gücü yoktur (Thomas, 2013:20). Kurumun araştırmaya değer görmediği şikayetleri incelememe ve incelemesi devam eden şikayetlerin geçerli nedenlerle sonlandırma hakk1 vardır.

Yerel yönetim ombudsmanı ulaşılabilirlik, tarafsızlık, hakkaniyetli ve gecikmeden yargılamanın yapılması, etkili karar verebilme ilkeleri doğrultusunda çalışacağını belirtmiştir (LGO, 2020). Yerel yönetim ombudsmanının kararlarından memnun olmayan vatandaşların şikâyetleri doğrultusunda yerel yönetim ombudsmanı gözcüleri kurulmuştur. Kurulma amacı verilen kararları incelemek ve dürüst olmayan yöntemleri ortaya çıkartmaktır. Dürüst olmayan yöntemlere yerel yönetim ombudsmanlarının yerel yönetimlerde çalışan personelin kötü yönetimlerini açığa çıkmaması için şikâyetleri engellemek örnek gösterilebilir.

Yerel yönetim ombudsmanının karşılaştığı bazı sorunlar vardır. Bunlar şikayetlerin zamanında sonuçlanamaması, bütçe kısıtlamaları, ombudsmanlığın bağımsızlığının sorgulanması ve alınan kararların vatandaşların isteği doğrultusunda olmamasıdır (Arap, 2015:77).

\subsection{Cezaevi ve Şartlı Tahliye Ombudsmanı}

Cezaevlerinde yaşanabilecek sıkıntılar isyana, kargaşaya sebep olabilir. Mahkumlarında şikayet mekanizmasından yararlanabilmesi için 1960'lar ve 1970'lerde cezaevi ombudsmanlığı için önemli çalışmalar yapılmıştır (Önen, 2019:444). 1982 yılında bağımsız bir şekilde kurulan cezaevi denetim kurulu ferdi 
şikayetlere yer vermemektedir. 1967 yılında göreve başlayan Parlamento Ombudsmanlığı, mahkumlar tarafindan gelen şikayetlerin az sayıda olduğunu ve bu şikayetlerin cezaevindeki adaletsizliği yansıtmadığını savunmuştur (Bradley, 1992:355). 1990 yılında Lord Justice Woolf tarafindan hazırlanan raporla sistemde değişikliğe gidilmiştir (Henham, 2000:290). Bu raporda meşruiyetin sağlanması için cezaevlerinde şikayet mekanizmasının gerekliliği savunulmuştur (Woolf ve Tumin, 1991:143). Raporla birlikte İngiltere ve Galler'de cezaevi ombudsmanlığı kurulmuştur (Seneviratne, 2010:350).

1994 yılında kurulan Cezaevleri ve Şartlı Tahliye Ombudsmanlığı (PPO) mahkumların şikayetlerini dikkate alan bir kurumdur. Cezaevi ombudsmanlığının hangi konular ile yetkili olduğu cezaevi hizmet belgelerinde yer almaktadır (Seneviratne, 2010:351). 2001 yılında kurumda bazı değişikliklere gidilmiştir. Ombudsman aynı zamanda şartlı tahliye servisi tarafindan denetlenenlerin şikayetlerini de kabul etmektedir. Bu dönemde gözaltında ölenlerin durumunun soruşturulması, göçmenlerin durumları yeni görevlerinden bazılarıdır (Owers, 2006:86). Cezaevleri ve Şartlı Tahliye Ombudsmanlığı'nın yetkili olduğu konular mahkumların bakımı, tedavisi, yönetimle ilgili karar ve eylemleridir. Kuruma şikayet edilemeyecek konular ise mahkeme tarafindan verilen mahkumiyet, ceza, sağlık şikayetleri, yasal işlem konusu olan davalardır (PPO, 2019).

Ombudsman adalet bakanı tarafindan atanmaktadır (Önen, 2019:20). Parlamento Ombudsmanı kendisine cezaevleri hakkında gelen şikayetleri Cezaevi ve Şartlı Tahliye Ombudsmanı'na yönlendirerek kurumun etkinliğini arttırmıştır. Şikayette bulunan mahkumlar Cezaevi ve Şartlı Tahliye Ombudsmanı'nın verdiği kararlardan hoşnut olmazlar ise Parlamento Ombudsmanı'na şikayet konusunu tekrar gönderebilir (Morris ve Henham, 1998:353). Cezaevi ve Şartlı Tahliye Ombudsmanı yasal olarak göreve başladığından beri Parlamento Ombudsmanı'nın iş yükü azalmıştır.

Ombudsman'a şikayet için belli koşullar gereklidir. Hükümlüler iç şikayet yöntemlerini bitirdiğinde ombudsmanlara erişme imkanı bulmaktadırlar. Erişim ise mektup, şikayet formu veya telefon ile sağlanmaktadır. Şikayet edilen konuyu öğrenen şikayetçi 12 ay içinde ombudsmana şikayette bulunmalıdır. Şikayet, cezaevi şikayet yönetimden cevap alınmasının ardından üç ay içinde yapılmalıdır. Şikayetlerin kabul edilmeme durumu da vardır. Meselenin yetki alanında olup olmadığının tespiti için şikayetler kontrol edilir. Şikayetler en kısa zamanda ele alınmaktadır. Şikayetçilere 10 gün içinde uygunluk kararı verilmesi hedeflenirken soruşturma 12 hafta içerisinde tamamlanması amaçlanmaktadır. Cezaevi ve Şartlı Tahliye Ombudsmanı'nın usül konusunda takdir yetkisi bulunmaktadır (PPO, 2019). Ombudsman uzlaşma ve çözüme odaklıdır. Uzlaşı sağlanamazsa şikayet kabul edilir ve resmi kaydı gerçekleştirilir. Rapor sunulabilmesi için şikayetin resmi kaydının olması gerekmektedir. Cezaevi ve Şartlı Tahliye Ombudsmanı cezaevi servisine şikayetler doğrultusunda öneride bulunabilir ancak kararlar bağlayıcı değildir (PPO, 2019). Cezaevi ve Şartlı Tahliye Ombudsmanı kaybedilen ve hasar görmüş mallar için tazminat, metoda ilişkin usulsüzlüklerin bulunduğu yerde bulguların kesilmesini, kaybolan paraların iadesinin gerçekleşmesini önerebilir (PPO, 2019).

Ombudsmanlık kurumunun en önemli özelliği bağımsız olmasıdır. Cezaevi ve Şartlı Tahliye Ombudsmanı'nın Adalet Bakanlığı ile olan ilişkisi göz önünde bulundurulduğunda bağımsızlığı sağlamanın diğer ombudsmanlık türlerine göre daha güç olduğunu söyleyebiliriz. Ombudsman Adalet Bakanı tarafindan atanmakta, bütçesini bu bakanlık vasıtasıyla hayata geçirmekte ve soruşturmalar sonucu oluşturduğu raporlarını yine Adalet Bakanlı̆̆ı' na iletmektedir. Adalet Bakanlığı Sekreterliği vasıtasıyla raporlar Parlamento'ya iletilmektedir (PPO, 2019).

\section{TÜRKIYE'DE KAMU DENETÇILİĞİ KURUMU}

İslamiyet öncesi Türk devletlerinde töre geleneği, toy, şölen, han-1 yağma, kurultay mekanizmaları ombudsmanlık kurumunun gerçekleştirdiği işlevleri yerine getirmektedir. İslamiyet sonrası Türk devletlerinde ise Divan-Adl/Divan-1 Mezalim kurumları bugünkü ombudsmanlık kurumunun temelini oluşturmaktadır. Osmanlı Devletinde, Divan-1 Hümayunun vatandaşların sorunları dinlenilerek çözüm üretilen bir işlevi bulunmaktadır. Şeyhülislamlık, Kadı'yul Kudat'lı gibi kurumlarda bu işlevlere sahiptir. Kamu Denetçiliği Kurumu'nun oluşmasında bu kurumların büyük bir payı bulunmaktadır (Alodalı ve Usta, 2017:169-174).

Türkiye'de ombudsmanlığa yönelik çalışmalar 1960'lı yıllarda başlamıştır. Bu dönemde çeşitli akademik çalışmalar yapılmıştır ancak devlet boyutunda bu kuruma yönelik bir çalışmaya rastlanmamaktadır. 1982 Anayasası'nın hazırlık aşamasında da kamu denetçileri kurulunun kurulması önerilmiştir (Sezen, 2001:84). 1982 Anayasası hazırlanırken Ankara Üniversitesi tarafından gerçekleştirilen çalışmada Kamu Denetçiliği Kurumu'nun kurulması öneriler arasında yer almış fakat bu dönemde Milli Güvenlik Konseyi bu hususu dikkate almamıştır (Arslan, 1992:1044). 
1991 yılında Devlet Planlama Teşkilatı'nın isteği üzerine Türkiye ve Ortadoğu Amme İdaresi Enstitüsü tarafindan yayınlanan Kamu Yönetimi Araştırma Projesi (KAYA) raporunda Devlet Denetleme Kurulu'nun kamu denetçisi olarak görev yapması tavsiye edilmiştir (TODAİE, 1991:43). Bu projenin hedefi merkezi idarenin başkent ve taşra teşkilatı ile yerel yönetimlere etkinlik ve verimlilik kazandırmak, günün şartlarına uygun hale getirilmesi, devlet kurumlarının amaçları doğrultusunda görev, yetki, sorumluluk, örgüt yapısı, personel sistemlerini incelemek ve sistemde oluşan aksaklık, bozuklukları tespit edip bu konular hakkında öneriler sunmaktır (Kalağan, 2010:73). Öte yandan Kamu Yönetimi Araştırma Projesinde denetim mekanizmalarının yetersizliğine değinilmiş ve Devlet Denetleme Kurulunun ombudsmanlık kurumu olarak görev yapması tavsiye edilmiştir (TODAİE, 1991:23).

18.07.1995 tarihinde Türkiye Büyük Millet Meclisi Genel Kurulu'nda 7. Beş Yıllık Kalkınma Planı onaylanmıştır. Bu plan 1996-2000 yıllarını kapsamaktadır. Plan'da vatandaşlar ile kamu yönetimleri arasında meydana gelen sorunların bir an önce çözülmesi amacı ile yargı organlarının ve bunların yoğunluğundan kaynaklanan sorunların dışında kalan, yargı organları ve yürütme organı ile de organik bir bağ içerisinde bulunmayan, dünyada birçok devlette ve Avrupa Birliği örgütü içerisinde de bulunan, vatandaşların devletle olan uyuşmazlıkları için başvurabildikleri bir Kamu Denetçiliği (ombudsmanlık) sisteminin Türkiye'de kurulmasının gerektiği fikri yer almaktadır (7. Beş Yıllık Kalkınma Planı, 1996:119).

8. Beş Yıllık ve 9. Kalkınma Planları'nda da Kamu Denetçiliği (ombudsmanlık) sisteminin kurulması gerektiği fikri yer almıştır. Dokuzuncu Kalkınma Planı'nın Kamuda İyi Yönetişim Özel İhtisas Komisyonu Raporu'nda, kamu denetçiliği (ombudsmanlık) sisteminin acilen kurulması gerektiği yer almaktadır (Kutlu vd., 2018:34).

55. Hükümet döneminde "Ombudsman Yasa Tasarısı Taslağı Hazırlama Komisyonu” kurulmuştur. Komisyon gerekli çalışmaları tamamlayıp raporunu "Kamu Sözcülüğü Kanun Tasarısı Taslăğ” adı ile 1998 yılında sunmuştur. Fakat taslak yasalaşamamıştır (Erhürman, 2000:156).

57. Hükümet döneminde Kamu Denetçiliği Kurumu'nun oluşturulmasına yönelik 14 Eylül 2000 tarihinde “Kaтu Denetçiliği Kurumu Kanunu Tasarısı" Bakanlar Kurulu'ndan geçip Türkiye Büyük Millet Meclisi'ne gönderilmiştir. Fakat tasarı kadük kalmıştır (Yağmurlu, 2018:180).

Kamu Yönetimi Temel Kanunu olarak hatırlanan 2004 yılında TBMM'nin kabul ettiği 5227 sayılı Kamu Yönetiminin Temel İlkeleri ve Yeniden Yapılandırılması Hakkında Kanun'da yerel yönetimlerde halk denetçisi (yerel yönetim ombudsmanı) kurulması önerilmektedir. $\mathrm{Bu}$ yerel yönetim ombudsmanının illerde yerel yönetimler ile vatandaşlar arasında oluşan uyuşmazlıkların çözümü için vatandaşların başvuru yapabilecekleri bir denetim organı olarak yer almaktadır. Bu Kanun, dönemin Cumhurbaşkanı tarafından yeniden görüşülmesi için Meclis'e gönderilmiş ve kanunlaşamamıştır (Şengül, 2007:136).

15.06.2006 tarihinde 5521 sayılı Kamu Denetçiliği Kurumu Kanunu'nu Meclis’te kabul edilmiş fakat dönemin Cumhurbaşkanı tarafından yeniden görüşülmesi için Meclis'e geri gönderilmiştir. 5548 sayılı Kamu Denetçiliği Kurumu Kanunu tasarısı Meclise sunulup kabul edilerek yasalaşmıştır ve 13.10.2006 tarihinde Resmi Gazete'de yayımlanmıştır. Ancak 5548 sayılı Kanun hakkında dönemin Cumhurbaşkanı TBMM'ye bağlı bir ombudsmanlık kurumu ile Anayasa'nın mevcut halinin uyuşmadığı görüşüyle kurulamayacağını belirterek ve 123 milletvekili tarafından Anayasa Mahkemesi'ne Kanun'un iptal edilmesi için başvuruda bulunulmuştur. Anayasa Mahkemesi 5548 sayılı Kanunu'nun tümünü oybirliği ile iptal etmiştir.

Kanun'un iptal edilmesinden sonra Anayasa'dan kaynaklanan bu durumu aşabilmek amaciyla 12 Eylül 2010 tarihinde halk oylamasına gidilmiştir. Halk oylaması ile Anayasa değişikliği paketi kabul edilmiş̧ir. Bu paket ile T.C. 1982 Anayasası'nın 74. maddesinin kenar başlığı "VII. Dilekçe, bilgi edinme ve kamu denetçisine başvurma hakkl" olarak değiştirilmiştir. Böylece anayasal engel ortadan kalkmıştır.

Anayasa değişikliğinin ardından 5548 sayılı Kanun'un birçok hükmünü barındıran yeni bir kanunu tasarısı hazırlanmış ve 5 Ocak 2011'de Türkiye Büyük Millet Meclisi'ne sunulmuştur. Bu yasa tasarısı 14.06.2012 tarihinde 6328 sayılı Kamu Denetçiliği Kurumu Kanunu olarak yasalaşmış ve 29.06.2012 tarihinde Resmi Gazete'de yayımlanmıştır.

6328 sayılı Kanun'un genel gerekçesinde 8. Beş Yıllık Kalkınma Planı'nda sunulan öneri hemen hemen aynı şekilde yer almıştır. Buna göre; vatandaşlar ile kamu yönetimleri arasında meydana gelen sorunların bir an önce çözülmesi amacı ile yargı organlarının ve bunların yoğunluğundan kaynaklanan sorunların dışında kalan, yargı organları ve yürütme organı ile de organik bir bağ içerisinde bulunmayan, dünyada birçok devlette ve Avrupa Birliği örgütü içerisinde de bulunan, vatandaşların devletle olan uyuşmazlıkları için başvurabildikleri bir Kamu Denetçiliği (ombudsmanlık) sisteminin Türkiye'de kurulmasının gerektiği öngörülmektedir. Kurum vatandaşlar ile kamu kurumları arasında var olabilecek uyuşmazlıklar için isabetli ve süratle karar alabilen, uyuşmazlıklarla 
ilgili öneriler sunabilen ve aynı zamanda idari yargıda oluşan yoğunluğu hafifletebilecek bir kuruma gerek duyulduğu gerekçede yer almaktadır.

6328 sayılı Kanun'un yürürlüğe girmesinin ardından bir kamu baş denetçisi ve beş kamu denetçisi seçilmiş ve göreve başlamışlardır. Kamu Denetçiliği Kanunu'na göre Kurum'un görevi kamu yönetimlerinin işleyişi noktasında vatandaşlıklardan gelen başvuruları incelemektir. Kurum'un adil olacağı, hakkaniyeti gözeteceği ve hukuki mevzuata uygun bir şekilde araştırma yapacağı ve kamu yönetimlerine öneriler sunacağı yasada yer almaktadır. Yasama ve yargının yetkisinde olan işler ile Türk Silahlı Kuvvetleri'nin temel hizmet alanında yürüttüğü görevleri için Kamu Denetçiliği Kurumu'na başvuru yapılamamaktadır (6328 sayılı Kanun, 5. Madde). Devlet ile ilgili olan ve kapsam dışında tutulmayan her alandaki başvuru kamu denetçisinin görev alanı içerisindedir. Türkiye'de ayrı alanlarda görevli özel amaçlı kamu denetçileri bulunmamaktadır. Örneğin yerel yönetimler, kadın, çocuk konuları için yalnız bu konular için görevlendirilmiş özel kamu denetçileri yoktur.

Kanun'a göre kuruma gerçek ve tüzel kişiler başvurabilir. Başvurular başvuran talep ederse gizli kalabilmektedir. Dilekçe yazılarak illerde valilik ilçelerde kaymakamlıklara başvurulur. Başvuru ücretsizdir ve 6 ay içerisinde sonuçlanmalıdır. Konu önce yargıya aksettirildiyse Kamu Denetçisi Kurumuna başvurduğu andan itibaren yargı süreci durdurulur ve karar başvuranı tatmin etmezse yargı süreci tekrardan başlayabilir (6328 sayıl1 Kanun, 17. Madde).

Kamu Denetçiliği Kanunu'na göre Kamu Baş denetçisi; Kamu denetçiliği kurumuna gelen şikâyetler doğrultusunda inceleme ve araştırma yapar ve idareye görüşler bildirir. Kanunun uygulamaya geçmesi için yönetmelik sunar. Düzenli olarak her yıl rapor hazırlar ve bu raporları kamuoyuna duyurur. Teşkilat içerisinde çalışanlar arasında ki iş bölümünü düzenler ve personel atamalarını yapar. Kanunda belirtilen diğer görevleri yerine getirir. Kamu Denetçiliği Kanunu'nda belirtilen görevlerin ifa edilmesinde baş denetçiye yardımcı olmak ve baş denetçinin verdiği görevleri yerine getirmek denetçinin görevleri arasındadır. Denetçi ve baş denetçinin görev süreleri 4 yıldır (6328 sayılı Kanun, 7. Madde).

\section{SONUÇ}

Ombudsmanlık kurumu ilk kez 1713 yılında İsveç’te uygulanmaya başlamıştır. İsveç kralı XII. Karl (Demirbaş Şarl)'ın İsveç-Rus Savaşı sonrasında Osmanlı Devleti'ne sığındığı süre zarfinda Osmanlı Devleti'nde yer alan birçok kurumdan etkilendiği ve ülkesinde görev yapan memurları kendi adına denetlemesi için yine bir kamu görevlisi olan ombudsmanı atadığı çeşitli kaynaklarda yer almaktadır.

Uzun yıllar yalnız İsveç’te uygulanan ama özellikle İkinci Dünya Savaşı sonrası dünyanın farklı yerlerinde birçok ülkede uygulanmaya başlanan bir kurumdur. Ombudsmanlık kurumu gelişmekte olan devletlerde adeta gelişmeye doğrudan katkı sağlayacak bir reçete olarak birçok devlette yer almıştır. Ombudsmanlık genel ve özel ombudsmanlık olmak üzere temelde iki türe ayrılmaktadır. Özel ombudsmanlık ise çocuk, sağlık, tüketici, avukat, yerel yönetimler, cezaevi, insan hakları ombudsmanlığı gibi pek çok örneği ile bugün birçok devlette yer bulmaktadır.

Ombudsmanlık kurumu vatandaşların haklarını gözetir, vatandaşlar ile kamu kurumları arasındaki uyuşmazlıkların çözülmesi için önerilerde bulunur. Ombudsmanın kararları bağlayıcı değildir ancak caydırıcılığa sahiptir. Ombudsmanlık kurumu meclis tarafından desteklenmeli ve kolay ulaşılabilir olmalıdır. Kurumun varlığıyla birlikte devlet ile vatandaş arasında güven ortamı oluşmaktadır. Ombudsman için birçok farklı kavram kullanılmakla birlikte kamu denetçisi, kamu hakemi, halkın avukatı öne çıkan kavramlar arasındadir.

Ülkemizde hukuki metinlerde kamu denetçiliği kavramı kullanılmaktadır. Kamu Denetçiliği Kurumu'na ilişkin çalışmalara 1960'lı yıllarda rastlanmaktadır. 1982 yılında da bu konuda yeni Anayasa'nın hazırlık aşamasında önerilere yer verilse de karşılık bulamamıştır. KAYA'da ve özellikle 7., 8. ve 9. Kalkınma Planı'nda Kamu Denetçiliği Kurumu'nun kurulması gerektiği ifade edilmiştir. 2010 y1lında gerçekleştirilen anayasa değişikliğine ilişkin halk oylaması ile kamu denetçiliğinin önündeki engel kalkmıştır. Halk oylaması ile Anayasa değişikliği paketi kabul edilmiştir. 2012 yılında 6328 sayılı yasa ile Kurum kanuni bir statüye kavuşmuştur. Türkiye'de kamu denetçisi genel bir kamu denetçisi özelliği göstermektedir. Devlet ile ilgili olan ve kapsam dışında tutulmayan her alandaki başvuru kamu denetçisinin görev alanı içerisindedir.

İngiltere'de ise Ombudsmanlık Kurumu'nun kurulması 1961 yılında önerilmiş, 1967 yılında ombudsmanlık kurumu Parlamento Komiseri adı ile kurulmuştur. İngiltere'de 1974 yılında çıkarılan mahalli idareler yasası ile yerel yönetimler ombudsmanlığı kurulmuştur. Kanun'da yerel yönetim komiseri ifadesi tercih edilmiştir. 1994 
yılında kurulan Cezaevleri ve Şartlı Tahliye Ombudsmanlığ 1 kurulmuştur. İngiltere'de ombudsmanlık kurumlarının ortak özellikleri; Kuruma kolay ulaşılabilir ve ücretsiz olmalıdır. Kurum diğer kamu kuruluşlarıyla yakın ilişkilerde bulunmalıdır. Ombudsmanın tavsiyeleri yol gösterici olmalı ve çözüm odaklı olmalıdır. Ombudsman adaletli ve tarafsız olmalıdır. Herhangi bir siyasi partiye yakınlığı olmamalıdır. Demokratik bir ortam için vatandaşların temel hak ve özgürlükleri gözetilmeli, idarelerin yanlışlarını fark etmesini sağlayarak kişilerin mağdur olmalarını engellenmelidir. Ombudsmanın kararları ise idarelerce benimsenmelidir. Ayrıca vatandaşların bilgilendirilmesi için kamuoyu oluşturulmalıdır.

İngiltere'de ombudsmanlık kurumu yaklaşık 50 y1llık bir tecrübeye sahiptir. Bir çok konuda özel ombudsmanlar kurulmuştur. Parlamento komiserliği, yerel yönetimler komiserliği, cezaevleri ve şartlı tahliye ombudsmanlığı bu özel ombudsmanlık türlerinden üçüdür. Türkiye'de son 8 yıldır kamu denetçiliği yasal bir zeminde yer almaktadır. Genel amaçlı olan kamu denetçisi devletin taraf olduğu uyuşmazlıkların çözümü için öneriler sunmakta ve başarılı sonuçlar elde etmeye çalışmaktadır.

\section{KAYNAKÇA}

AKTAN, Tahir (1989), Kamu İdaresi, Uludağ Üniversitesi Yayını, Bursa, 2. Bask1.

ALODALI, M. Fatih Bilal ve USTA, Sefa (2017), "Türk Yönetim Geleneğinde Hesap Verebilirlik Mekanizmaları: Divan-ı Mezalim ve Kamu Denetçiliği Kurumu”, Strategic Public Management Journal, S.3(6), ss.168-184.

ALTUĞ, Yılmaz (2002), Kamu Denetçisi Ombudsman, İstanbul Üniversitesi Yayını, İstanbul.

ALTUN, Murat ve KULUÇLU, Erdal (2005), "Doktrin ve Mevzuat Işı̆̆ında Kamuoyu Denetimine Genel Bir Bakı̧̧”, Sayıştay Dergisi, S.56, ss.23-51.

ARAP, Sultan Kavili (2015), “40. Yllında İngiltere'de Yerel Yönetim Ombudsmanı”, Ege Akademik Bakış Dergisi, S.15(1), ss.65-80.

ARI, Serdar (2017), "İsveç, İngiltere, Fransa ve Türkiye Ombudsmanlık Kurumları: Karşılaştırmalı Bir Analiz", International Idea Studies Jornual, S.3(3), ss.135-151.

ARSLAN, Süleyman (1986), “Íngiltere’de Ombudsman Müessesesi”, Amme İdaresi Dergi, S.19(1), ss.157172.

ARSLAN, Süleyman (1992), "Yıldırım Uler'in Konuşmasına Katkı", I. Ulusal İdare Hukuku Kongresi Bildiriler Kitabı, Danıştay Matbaası, Ankara, 3. Kitap (Çeşitli İdare Hukuku Konuları).

ATAMAN, Taykan (1993), “Ingiltere'de Ombudsman Kurumu (İdarenin Parlamento Tarafindan Denetimi)”, Türk İdare Dergisi, S.400, ss.217-255.

ATAMAN, Taykan (1997), "Ombudsman ve Temiz Toplum", Yeni Türkiye Dergisi, S.14, ss.779-789.

ATAY, Cevdet (1999), Devlet Yönetimi ve Denetimi, Alfa Yayınları, İstanbul, 2. Bask1.

AVŞAR, Zakir (2012), Ombudsman: İyi Yönetilen Türkiye İçin Kamu Hakemi, Hayat Yayın Grubu, İstanbul.

AYDIN, Kadir (2018), “Ombudsmanlık (Kamu Denetçiliği) Kurumu ve Türkiye Uygulaması”, Yayınlanmamış Yüksek Lisans Tezi, Karadeniz Teknik Üniversitesi, Sosyal Bilimler Enstitüsü, Trabzon.

BİLGE, Semih ve DAŞKAYA, Nurten (2015), "Mahalli İdarelerde İç Denetimin Değerlendirilmesi: Türkiye Örneği”, Maliye Dergisi, S.168, ss.109-110.

BRADLEY, Anthony Wilfred (1992), "Sachsenhausen, Barlow Clowes - and Then", Public Law, S.3, ss.353357.

BÜYÜKAVCI, Mustafa (2008), “Ombudsmanlık Kurumu”, Ankara Barosu Dergisi, S.4, ss.10-13.

COŞKUN, Bayram (2002), “Türk Kamu Yönetiminde İdari Denetim Süreci ve Bu Süreç İ̧̧inde Ortaya Çıkan Sorunlar”, Türk İdare Dergisi, S.437, ss.81-104.

ÇAKMAK, Caner (2008), “Kamu Denetiminde Kamu Denetçiliği (Ombudsman) Kurumunun Türkiye’de Yeri ve Önemi”, Yayımlanmamış Yüksek Lisans Tezi, Dokuz Eylül Üniversitesi Sosyal Bilimler Enstitüsü, İzmir. 
ÇELIKSSOY, Emine ve BAYAN, Büşra - Genel ve Özel Amaçlı Ombudsmanlık Örnekleri: İngiltere ve Türkiye

ERDENGİ, Tevfik Bora (2009), “Ombudsman: Dünya Uygulamaları ve Türkiye”, Yayımlanmamış Doktora Tezi, Hacettepe Üniversitesi Sosyal Bilimler Enstitüsü, Ankara.

ERDOĞMUŞ, Osman (2006), “Kamu Yönetiminde İdari ve Denetsel Açıdan Ombudsman Kurumu; Türkiye Örneği $”$, Yayımlanmış Yüksek Lisans Tezi, Ankara Üniversitesi Sosyal Bilimler Enstitüsü, Ankara.

ERHÜRMAN, Tufan (2000), "Türkiye İçin Nasıl Bir Ombudsman Formülü”, Ankara Üniversitesi Hukuk Fakültesi Dergisi, S.49(1-4), ss.155-180.

ERYILMAZ, Bilal (2013), Kamu Yönetimi, Umuttepe Yayınları, Kocaeli, 6. Bask1.

FENDOĞLU, Hasan Tahsin (2010), "Kamu Denetçiliği (Ombudsmanlık)", Analiz, SDE (Stratejik Düşünce Enstitüsü) Yayını, Ankara.

GİRITLİ, İsmet, BİLGEN, Pertev ve AKGÜNER, Tayfun, (2006), İdare Hukuku, Der Yayınları, İstanbul.

GÖZÜBÜYÜK, A. Şeref (2008), Türkiye’nin Yönetim Yapısı, Turhan Kitabevi, Ankara, 10.Baskı.

HENHAM, Ralph (2000), "Some Alternative Strategies for Improving the Effectiveness of the English Prisons Ombudsman Scheme", Howard Journal, S.39(3), ss.290-305.

KALAĞAN, Gökhan (2010), “Cumhuriyet Dönemi Türk Kamu Bürokrasisinde Yeniden Yapılanma ve Yönetsel Reform Çalışmaları”, Süleyman Demirel Üniversitesi Vizyoner Dergisi, S.2(1), ss.65-84.

KAZANCI, Metin (2016), Kamuda ve Özel Kesimde Halkla İlişkiler, Turhan Kitabevi, Ankara.

KILAVUZ, Raci, YILMAZ, Abdullah ve İZCI, Ferit (2003), "Etkin Bir Denetim Aracı Olarak Ombudsmanlı ve Türkiye'de Uygulanabilirliği”, Cumhuriyet Üniversitesi İktisadi ve İdari Bilimler Dergisi, S.4(1), ss.49-68.

KÖSE, Hacı Ömer (2000), Dünyada ve Türkiye'de Yüksek Denetim, Sayıştay Yayını, Ankara.

KULUÇLU, Erdal (2006), “Yönetimin Denetiminden Denetimin Yönetimine”, Sayıştay Dergisi, S.63, ss.3-37.

KUTLU, Önder, SEVINÇ, İsmail ve KAHRAMAN, Selçuk (2018), "Türkiye'de Kalkınma Planları Çerçevesinde Avrupa Birliği Katılım Sürecinin Değerlendirilmesi”, KMÜ Sosyal ve Ekonomik Araştırmalar Dergisi, S.20(34), ss.29-40.

KÜÇÜKÖZYİĞİT, Hüseyin Galip (2006), “Ombudsmanlı Kurumu - Hukuksal ve Siyasal Bir İnceleme”, Uluslararası Hukuk ve Politika Dergisi, S.2(5), ss.90-111.

LGO (2013-2016), Annual Report and Accounts, http://www.lgo.org.uk/information centre/reports/lgoannual-reports (Erişim tarihi: 16.03.2020).

LGO (2020), E-Documants, https://www.lgo.org.uk/make-a-complaint, (Erişim Tarihi: 17.03.2020).

MORRIS, P. E. ve HENHAM, Ralph Jean (1998), “The Prisons Ombudsman: A Critical Review”, European Public Law, S.4(3), ss.345-378.

MUTTA, Serdar (2005), İdarenin Denetlenmesi ve Ombudsman Sistemi, Kazancı Hukuk Yayınları, İstanbul.

OWERS, Anne (2006), “The protection of prisoners' Rights in England and Wales”, European Journal on Criminal Policy and Research, S.12(2), ss.85-91.

ÖKTEN, Serkan ve TURHAN, Gökhan (2014), “Avrupa Birliği'nde Ombudsmanlık”, Süleyman Demirel Üniversitesi Sosyal Bilimler Enstitüsü Dergisi, S.1(19), ss.213-224.

ÖNEN, Semih Mustafa (2019), “Kamu Denetçisi (Ombudsman)”, Kamu Yönetimi Ansiklopedisi (Ed. Yasemin Mamur Işıkcı - Esmeray Alacadağl1), Astana Yayınları, Ankara, 2. Bask1, ss.61.

ÖZDEN, Kemal (2010), Ombudsman Yeni Yönetim Anlayışı İçin Bir Model, Tasam Yayınları, İstanbul.

ÖZDEMİ, Birol (2015), Kamu Denetçiliği Kurumunun İşlevi, Yapısı ve Devlet Teşkilatındaki Konumu, Adalet Yayınevi, Ankara.

PAYASLIOĞLU, Arif Turgut (1969), “Yönetimde Davaları Azaltma Yolları”, Amme İdaresi Dergisi, S.2(3), ss.3-1.

PPO (2019), "Terms of Reference", Prisons and Probation Ombudsman, https:// www.ppo.gov.uk/about/vision-and-values/terms-of-reference/ (Erişim Tarihi: 16.03.2020). 
SENEVIRATNE, Mary (2013), “Ombudsmen and Prisoner Complaints in the UK”, Journal of Social Welfare and Family Law, S.34(3), ss.339-356.

SEZEN, Seriye (2001), "Ombudsman: Türkiye İçin Nasıl Bir Çözüm? Kamu Denetçiliği Kurumu Kanunu Tasarısı Üzerine Bir Değerlendirme", Amme İdaresi Dergi, S.34(4), ss.71-96.

ŞENGÜL, Ramazan (2007), “Türkiye’de Kamu Yönetiminin Etkin Denetlenmesinde Yeni Bir Kurum: Kamu Denetçiliği Kurumu”, Kocaeli Üniversitesi Sosyal Bilimler Enstitüsü Dergisi, S.2(14), ss.126-145.

TEMİZL, Zekeriya (1997), Yurttaşın Yönetime Karşı Korunmasında Bağımsız Bir Denetim Organı Ombudsman, IULA - EMME Yayınları, İstanbul.

THOMAS, Richard, MARTIN, Jim ve KIRKHAM, Richard (2013), External Evaluation of The Local Government Ombudsman in England, http://www.lgo.org.uk/downloads/About\%20 us/Governance/1777-CLA-2008-Evaluation-of-the- LGO-The-Final-Report-2-2-.pdf, (Erişim Tarihi: 16.03.2020).

TODAİE (1991), Kamu Yönetimi Araştırması Genel Rapor, TODAİE Yayınları, Ankara.

TORTOP, Nuri (1998), “Ombudsman Sistemi ve Çeşitli Ülkelerde Uygulanması”, Amme İdaresi Dergisi, S.31(1), ss.3-11.

TORTOP, Nuri, İSBİR, Eyyup Günay, AYKAÇ, Burhan Aykaç, YAYMAN, Hüseyin ve ÖZER, Mehmet Akif (2007), Yönetim Bilimi, Yargı Yayıncılık, Ankara.

ULUĞ, Feyzi (2004), “Kamu Yönetimi Temel Kanunu Tasarısı Işı̆̆ı̆nda Kamu Denetim Sisteminde Yeniden Yapılanma”, Amme İdaresi Dergisi, S.37(2), ss.97-122.

USTA, Sefa ve AKINCI, Abdulhavap (2016), "Kamu Yönetiminde Hesap Verebilirlik Mekanizması Olarak Ombudsmanlık Kurumu: Almanya Örneği”, Journal of Human Sciences, S.13(2), ss.2735-2749.

YAĞMURLU, Aslı ( 2018), "Şikayet Hakkı Ekseninde Halkla İlişkiler Mekanizması Olarak Kamu Denetçiliği”, Amme İdaresi Dergisi, S.51(1), ss.167-194.

Yedinci Beş Yıllık Kalkınma Planı (1996), Yedinci Beş Yıllık Kalkınma Planı, DPT Yayını, Ankara, http://www.sbb.gov.tr/wp-content/uploads/2018/11/Yedinci-Beş-Yıllık-Kalkınma-Planı-1996-2000, (Erişim Tarihi: 27.03.2020).

ZENGIN, Gökhan (2017), “Yerel Yönetimlerde Kamu Denetçiliği: İngiltere Yerel Yönetim Ombudsmanlığı”, Strategic Public Management Journal, S.3(6), ss.35-56.

WOOLF, Harry Kenneth ve TUMIN, Stephen (1991), Prison Disturbances, Prison Reform Trust, Londra.

6328 sayılı Kamu Denetçiliği Kurumu Kanunu (Erişim Tarihi: 05.11.2019).

https://www.mevzuat.gov.tr/MevzuatMetin/1.5.2709.pdf (Erişim Tarihi: 25.03.2020). 